\title{
Internal Structure and Ice Content of Reichenkar Rock Glacier (Stubai Alps, Austria) Assessed by Geophysical Investigations
}

\author{
H. Hausmann, ${ }^{1}$ K. Krainer, ${ }^{2}$ E. Brückl ${ }^{1 *}$ and W. Mostler ${ }^{2}$ \\ 1 Institute of Geodesy and Geophysics, Vienna University of Technology, Vienna, Austria \\ 2 Institute for Geology and Paleontology, University of Innsbruck, Innsbruck, Austria
}

\begin{abstract}
The Reichenkar rock glacier (Tyrol, Austria) is a typical tongue-shaped, $1400 \mathrm{~m}$ long, ice-cored active rock glacier, which connects to a debris-free cirque glacier. Aerial photographs from 1954 and 1990 indicate its mean surface velocity to be $0.6 \mathrm{~m} / \mathrm{a}$ while a photograph from 2003 and annual global positioning system (GPS) measurements since 1998 show that velocities in the past decade have increased to $3 \mathrm{~m} / \mathrm{a}$. Integration of ground-penetrating radar (GPR), seismic and gravimetric data reveals that the Reichenkar rock glacier consists of four layers. The uppermost debris layer has an average thickness of about $5 \mathrm{~m}$ and is underlain by ice-rich permafrost with an average thickness of about $25 \mathrm{~m}$. A prominent reflector detected by GPR is identified as the top of an unfrozen till layer located a few metres above the bedrock. Seismic refraction data clearly indicate the boundary between till and bedrock. The geophysical interpretation shows that the ice-rich permafrost of the rock glacier has an ice content of 45-60\%, depending on assumptions concerning the air content of the ice. Creep velocities calculated from the geophysical model, ice contents and an extension of Glen's flow law are in good accordance with observed surface velocities. Copyright (C) 2007 John Wiley \& Sons, Ltd.
\end{abstract}

KEY WORDS: rock glacier; gravimetry; GPR; seismic refraction; creep; mountain permafrost

\section{INTRODUCTION}

Internal structure and ice content are key factors controlling the dynamics and evolution of active rock glaciers. This information can be derived either from direct observations (e.g. borehole logs, outcrops and tunnels) or from surface-based geophysical methods such as seismic refraction, geoelectrics, groundpenetrating radar (GPR) and gravimetry. Until the early 1990s seismic refraction and direct current (DC) resistivity soundings were common methods to assess

\footnotetext{
* Correspondence to: Prof. Dr E. Brückl, Research Group Geophysics, Institute of Geodesy and Geophysics, Vienna University of Technology, Gusshausstrasse 27-29/1282, A-1040 Vienna, Austria. E-mail: ebrueckl@mail.tuwien.ac.at
}

Copyright (C) 2007 John Wiley \& Sons, Ltd. the thickness of permafrost and to deduce the origin of the permafrost ice (Barsch, 1973; King, 1976; King et al., 1987). During the project Permafrost and Climate in Europe (PACE) a broad range of geophysical methods was applied to determine the internal structure as well as the vertical and lateral distribution of permafrost in high mountain environments (Vonder Mühll et al., 2001, 2002; Hauck, 2001; Hauck and Vonder Mühll, 2003a, 2003b; Hauck et al., 2004). Vonder Mühll et al. (2000) suggest that useful combinations of geophysical techniques in Alpine permafrost environments include seismic surveys with DC resistivity and gravimetry with GPR. Nowadays even DC resistivity data are usually processed with algorithms that allow two-dimensional imaging of the subsurface (Hauck et al., 2003).

Received 1 March 2006

Revised 31 July 2007

Accepted 23 September 2007 
Few boreholes are available from rock glaciers (e.g. Haeberli, 1990; Vonder Mühll and Holub, 1992; Hoelzle et al., 1998; Arenson et al., 2002; Vonder Mühll et al., 2003; Arenson and Springman, 2005b). Haeberli et al. (2006) summarised these observations in a threefold classification based on ice distribution: (1) massive ice with dispersed debris and intercalated debris-laden ice, overlying a basal layer of rock; (2) a few metres to tens of metres of debris-laden ice overlying massive ice; and (3) ice/rock mélange throughout. Besides solid rock and ice, ice-rich core samples of rock glaciers contain air voids with a volumetric air content up to 25\% (Wagner, 1990; Arenson, 2002; Arenson et al., 2004). Thus, zones of circulating water or air can exist within or below the permafrost body of a rock glacier (Haeberli et al., 2006).

Previous publications on the Reichenkar rock glacier focused on geology, geomorphology, hydrology and surface velocities (Krainer and Mostler, 2000a, 2000b, 2002, 2006; Krainer et al., 2002; Chesi et al., 2003). In this study, we present an integrated geophysical approach to investigate its internal structure and provide information on the ice content of the permafrost body using a three-phase model (rock, ice and air). We calculate the creep velocity from the structural model, the ice content and an extension of Glen's flow law, in order to test whether the geophysical model can explain recently observed high surface velocities.

\section{STUDY SITE}

The Reichenkar rock glacier is located in a small, northeast-facing side-valley ('Inneres Reichenkar') of the Sulztal in the western Stubai Alps, Tyrol, Austria (Figure 1). The landfrom is a tongue-shaped, $1400 \mathrm{~m}$ long, ice-cored rock glacier, up to $260 \mathrm{~m}$ wide in its upper part, 170-190 m wide in its lower part and with an area of $0.27 \mathrm{~km}^{2}$ (Krainer and Mostler, 2000b) (Figure 2a). The rock glacier extends from an elevation of $2750 \mathrm{~m}$ a.s.l. down to $2310 \mathrm{~m}$ a.s.l. The active front is $33 \mathrm{~m}$ high and has a steep slope $\left(41^{\circ}\right)$.

The surface of the Reichenkar rock glacier is characterised by well-developed, longitudinal furrows and ridges in the upper part and transverse furrows and ridges in the lower part. The debris layer is very coarse near the surface, containing blocks up to several metres in diameter, but is much finer grained beneath. This debris is about $70 \%$ amphibolite and $30 \%$ eclogite by volume (Figure 2a). Bedrock in the lower part of the rock glacier (the investigated area) is biotite-plagioclase gneiss (Krainer and Mostler, 2000a).

Analysis of aerial photographs from 1954, 1990 and 2003 (Figure $2 b$ and $2 \mathrm{c}$ ) shows that the creep velocity of the rock glacier increased from 0.6 to $3 \mathrm{~m} / \mathrm{a}$ over this period. Annual GPS measurements between 1997 and 2004 give a mean horizontal velocity of $2.2 \mathrm{~m} / \mathrm{a}$ and a mean vertical change of $0.5 \mathrm{~m} / \mathrm{a}$, and also show a steady increase in horizontal velocities (Figure 3)

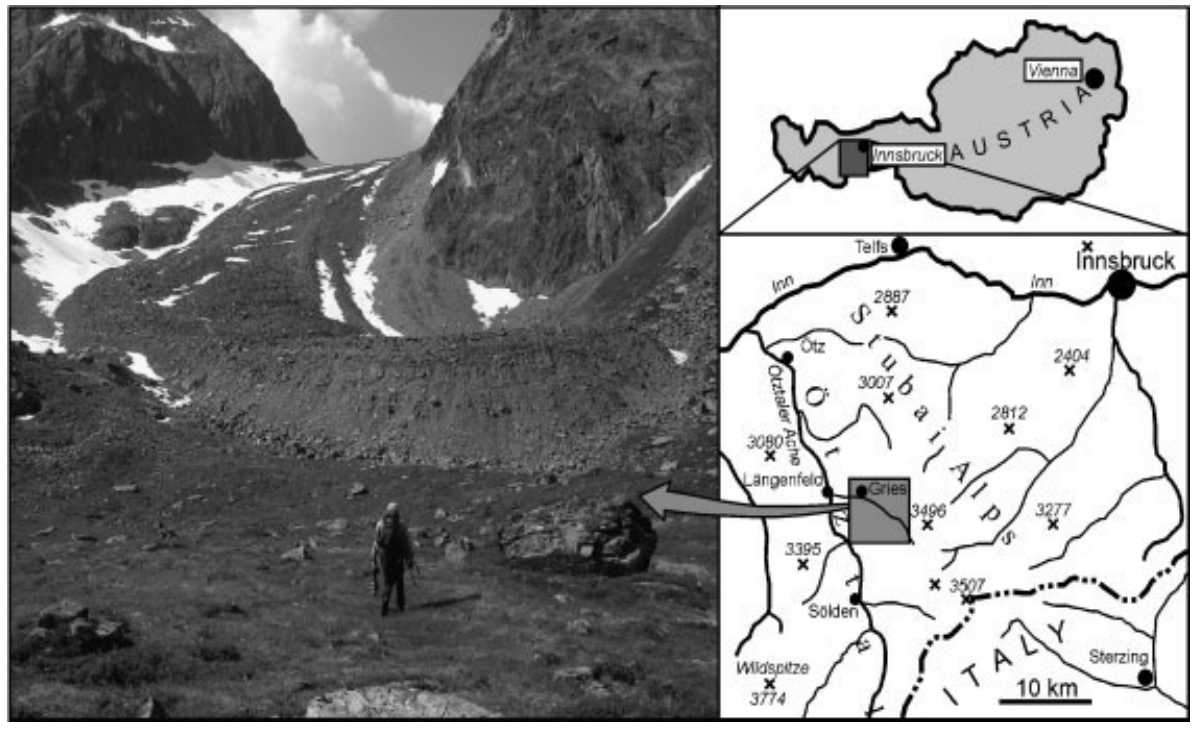

Figure 1 Location map and view of the Reichenkar rock glacier towards the south. 

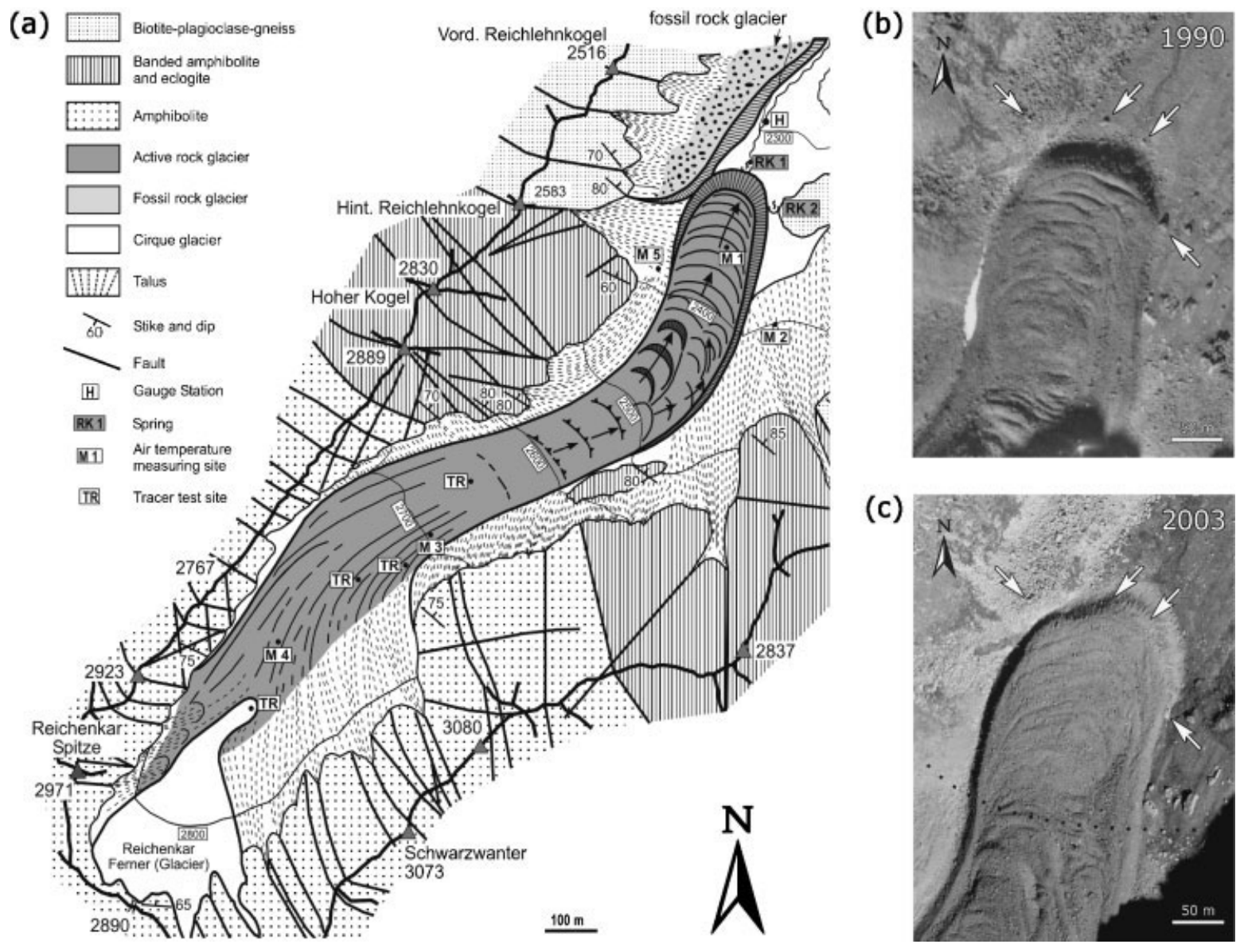

Figure 2 (a) Geological map of the Reichenkar rock glacier. (b) Aerial photograph from 1990, reproduced by courtesy of the Federal Office of Metrology and Surveying in Vienna (EB 2006/00073). (c) Aerial photograph from 2003, reproduced by permission of the Administration of Tyrol/tiris. The white arrows (in (b) and (c)) are reference points to display the large displacements between 1990 and 2003. Notable is the disappearance of two blocks in the front of the rock glacier. Geophysical investigations were carried out in the area between the front wall and the dotted line (c). In the northeastern part of (b) and (c) discharge from the rock glacier emerges from above a silty till layer.

(Chesi et al., 2003; Krainer and Mostler, 2006). The maximum measured surface velocity of almost $3 \mathrm{~m}$ occurred in 2003-04 along the longitudinal axis of the lower part of the rock glacier. The rock glacier front advanced $\sim 30 \mathrm{~m}$ from 1990 to 2003 , which is in agreement with the observed average displacement determined from GPS. Continuous GPS measurements over 46 days during summer 2002 showed fairly constant creep rates averaging $6 \mathrm{~mm} / \mathrm{d}$, independent of precipitation/discharge and ground surface temperature.

Meltwater from the rock glacier is released from a spring above a fine-grained (silty) till layer at the foot of the steep front (location RK1 in Figure 2a). Dye tracer tests showed high velocities
$(3.5-5.5 \mathrm{~m} / \mathrm{min})$ of the meltwater flow through the rock glacier, indicating channelised flow along a network of conduits (Krainer and Mostler, 2002). Strong seasonal and diurnal variations characterise the discharge.

\section{GEOPHYSICAL INVESTIGATIONS}

GPR, seismic refraction and gravimetry were used to interpret the internal structure and ice content of the Reichenkar rock glacier. First, GPR was used to derive the top of an unfrozen sediment layer (Figure 4a). Second, the depth to ice-rich permafrost was determined using seismic refraction (Figure $4 b$ ). 


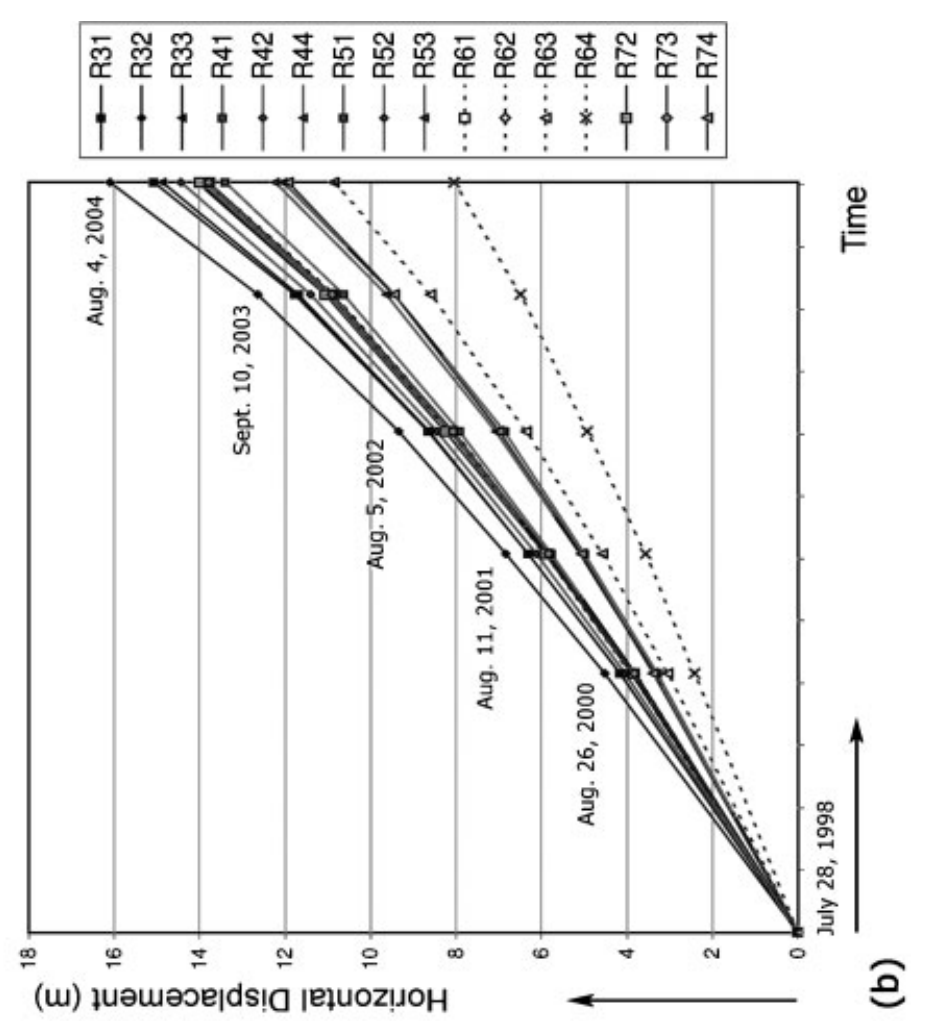

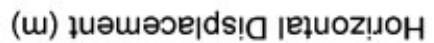




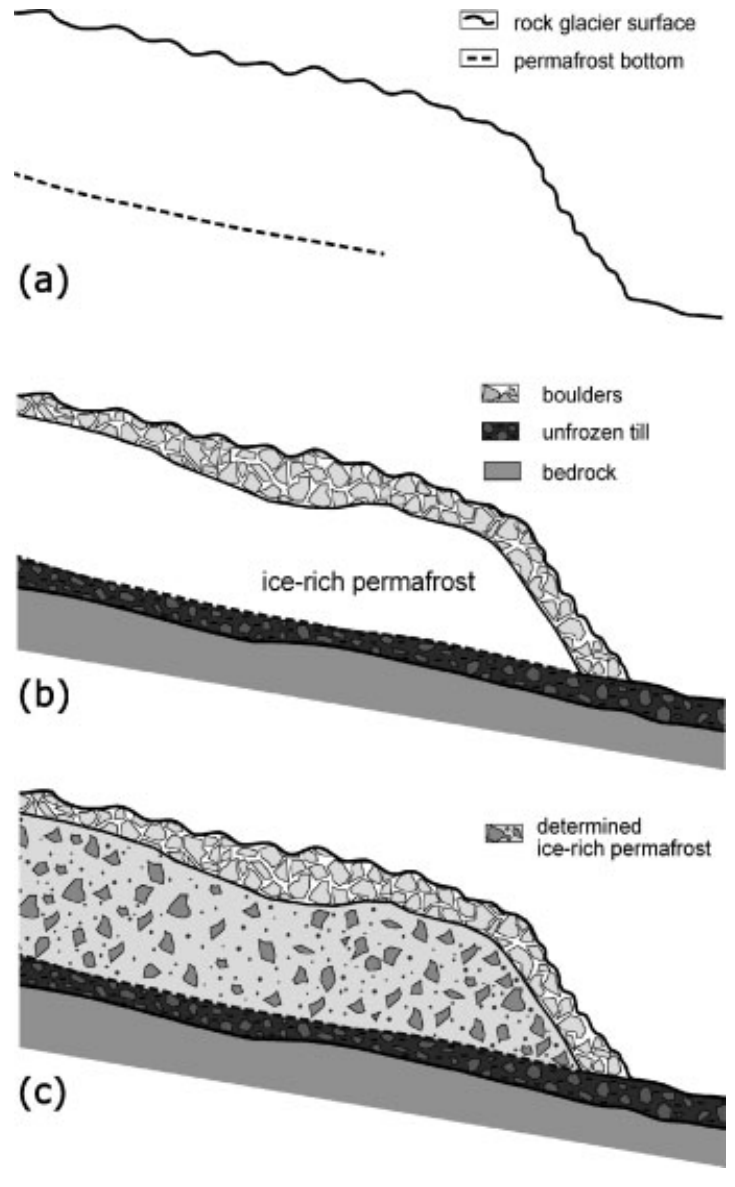

Figure 4 Integration of geophysical methods: (a) Information from GPR; (b) combination of (a) with information from seismic refraction; (c) combination of (a) and (b) with information from gravimetry.

The combination of these results also provided the depth to bedrock. Finally, gravimetric information was used to calculate the ice content of the permafrost body (Figure $4 c$ ).

\section{GPR}

The internal structure of rock glaciers has been studied by GPR since 1982 using centre frequencies between 50 and $300 \mathrm{MHz}$ (Haeberli et al., 1982; Haeberli, 1985; King et al., 1987; Vonder Mühll, 1993). Penetration depths up to $40 \mathrm{~m}$ were obtained recently at rock glaciers using centre frequencies between 15 and $50 \mathrm{MHz}$ (e.g. Berthling et al., 2000, 2003; Isaksen et al., 2000; Degenhardt, 2002; Degenhardt et al., 2003; Maurer and Hauck, 2007). Arcone et al. (1998) highlighted the potential of GPR for permafrost investigations in Alaska. Lehmann and Green (2000) emphasised the importance of topographic migration for steep shallow reflectors below rugged surfaces like rock glaciers. Typical values for the mean wave velocity of the ice-rich permafrost of rock glaciers range between 0.14 and $0.15 \mathrm{~m} / \mathrm{ns}$ (Schmöller and Fruhwirth, 1996; Wale, 1999; Isaksen et al., 2000; Lehmann and Green, 2000; Berthling et al., 2003). Degenhardt and Giardino (2003) produced a different value $(0.12 \mathrm{~m} / \mathrm{ns})$.

We used the GSSI SIR System 2000 in combination with a multiple low frequency (MLF) antenna. Profiles were measured using a centre frequency of $35 \mathrm{MHz}$ and constant antenna spacing in point mode (constant-offset profiling). The distance between transmitter and receiver was $4 \mathrm{~m}$ and the sampling interval was $1 \mathrm{~m}$. The antennas were oriented perpendicular to the profile direction. The main recording parameters were $1000 \mathrm{~ns}$ time range, 1024 samples/scan, 16 bits/ sample and 32-fold vertical stacking. One longitudinal profile (147) and two transverse profiles $(146,148)$ were measured (Figure 5a). Best results were achieved in winter when the rock glacier was covered with a thick layer of snow and when meltwater was absent (Krainer et al., 2002). Figure 6a shows an unprocessed section of profile 147. A continuous reflector (R1) is apparent and can be correlated in all other sections after data processing (Figure 6). No transparent zone (Berthling et al., 2003) was detected but a few vague reflections and scattering can be observed above reflector R1.

The lack of availability of common midpoint (CMP)-profiles complicates determination of the mean wave velocity. Therefore, deconvolution was applied to identify parts of diffraction hyperbolae in the lower parts of the sections. The corresponding values for the mean velocity range between 0.14 and $0.15 \mathrm{~m} / \mathrm{ns}$. To verify these values we used different velocities for the migration $\left(0.11<v_{\text {till,gpr }}<0.19 \mathrm{~m} / \mathrm{ns}\right.$ ) (for a list of symbols see Appendix A) and evaluated the shape of the migrated diffraction hyperbolae. We arrived at a value of $v_{\text {till,gpr }}=0.145 \mathrm{~m} / \mathrm{ns}$ for the conversion of two-way reflection times $\left(t_{g p r}\right)$ to depths $\left(h_{t i l l}\right)$ which agrees with previously reported CMP measurements. The penetration depth obtained ( $30 \mathrm{~m}$ in case of $\mathrm{R} 1$ ) is typical for rock glaciers.

Amplitude and waveform modelling was used to investigate the origin of the reflector R1. The different media in the model (debris, ice-rich permafrost and bedrock) are described by dielectric permittivity and conductivity (Arcone et al., 1995; Berthling et al., 2003; Hauck et al., 2003; Musil et al., 2006). For the till layer a range of values was used for dielectric 
(a)

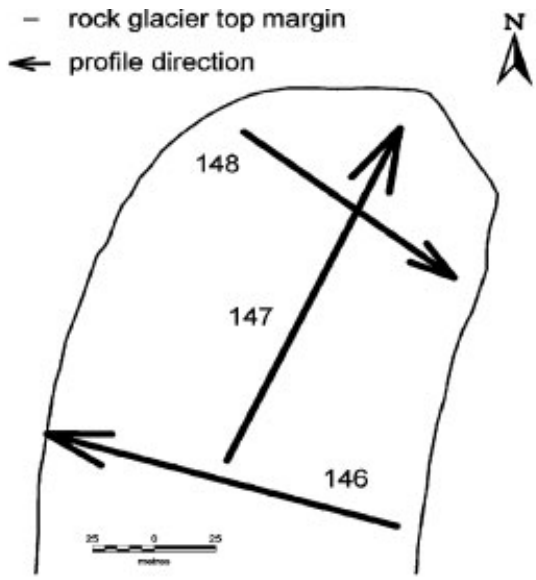

(b)

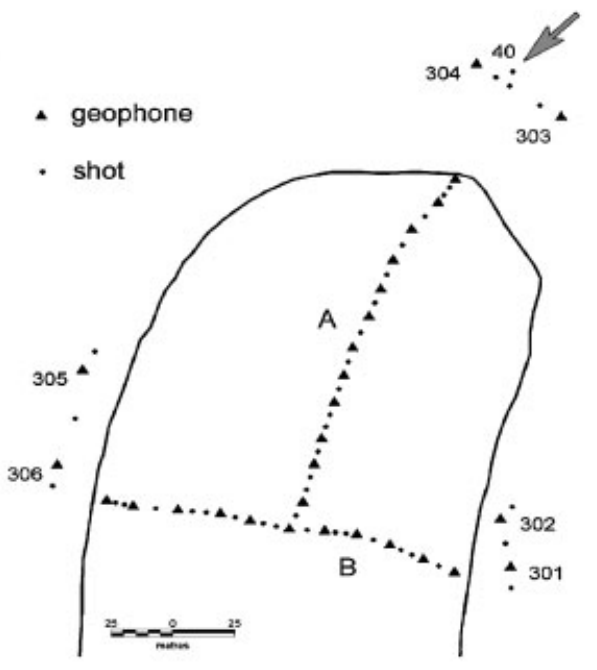

(c)



Figure 5 Layout of geophysical measurements; (a) GPR; (b) seismic refraction; (c) gravimetry. permittivity (10-30) and conductivity (0.00002-0.2 S/ $\mathrm{m})$. The reflection coefficient of radar waves at normal incidence is +0.27 for an ice-air boundary, -0.67 for an ice-water boundary and -0.8 for an air-water boundary (Arcone et al., 1995; Stuart et al., 2003). The modelled radar data show that a high contrast in permittivity and conductivity is necessary to produce the observed high amplitudes and the waveform shape of the reflector R1. Thus, the reflector R1 is interpreted as the top of a wet till layer. This layer can be extrapolated to the terrain surface at the front of the rock glacier, where a fine-grained (silty) till layer is present.

\section{Seismic Refraction}

Seismic refraction has been successfully used on rock glaciers since about 1970 (e.g. Barsch, 1971; Potter, 1972; King, 1976; Vonder Mühll, 1993; Musil et al., 2002) and more recently seismic refraction tomography has been employed for permafrost studies (Hauck, 2001; Vonder Mühll et al., 2002; Hauck et al., 2004). Seismic P-wave velocities of rock glaciers range between 250 and $1100 \mathrm{~m} / \mathrm{s}$ for the debris layer and between 2700 and $4050 \mathrm{~m} / \mathrm{s}$ for ice-rich permafrost (e.g. Vonder Mühll, 1993; Musil et al., 2002).

Seismic refraction measurements were carried out using 40 shots and 30 single channel miniature recorders (Reftek 125) placed along profiles A and B and at locations outside the rock glacier (Figure $5 b$ ). Seismic energy was generated by the use of detonating cord blasted at the surface and all shots were recorded simultaneously by all receivers. The average spacing of the geophones $(4.5 \mathrm{~Hz}$, vertical) along the two profiles on the rock glacier was $15 \mathrm{~m}$. Since one or two shot points were arranged between two consecutive geophones, the average sampling distance was $6.5 \mathrm{~m}$ along profiles A and B. The temporal sample interval was $1 \mathrm{~ms}$. A sample record is shown in Figure 7a. All first arrival travel times are plotted in Figure 7b. Figure 7c shows all traces with geophones and shots on the rock glacier stacked to offset bins of $8 \mathrm{~m}$ width. Both the stack and the travel times resolve three layers: debris, ice-rich permafrost and bedrock. Average velocities estimated by correlation of the different phases are: $v_{\text {debris }}=950 \mathrm{~m} / \mathrm{s}, \quad v_{\text {icePf }}=$ $3300 \mathrm{~m} / \mathrm{s}$ and $\mathrm{v}_{\text {bedrock }}=4100 \mathrm{~m} / \mathrm{s}$. The P-wave velocity of the ice-rich permafrost is significantly lower than the velocity of pure ice at $0^{\circ} \mathrm{C}(\sim 3750 \mathrm{~m} / \mathrm{s})$. This may indicate (i) a reduction of the frozen contact between ice and debris within the ice-rich permafrost and subsequent formation of a water film (cf. Vonder Mühll, 1993; Barsch, 1996; Musil, 2002) and/or (ii) numerous air voids within the ice (Arenson, 2002). The velocity of the 



Figure 6 (a) GPR profile 147 without data processing (constant gain). (b-d) GPR profiles processed with bandpass filter, background removal, gain adjustment, depth conversion and elevation correction. The black crosses indicate the interpreted horizon R1: (b) profile 146; (c) profile 147; (d) profile 148. 



Figure 7 Representation of seismic data: (a) Record section (seismogram arranged by the absolute offset) of shot 40 (highlighted in Figure 5b). Noticeable are the shorter travel times to geophones (301-304) placed outside the rock glacier. (b) First arrival travel times versus absolute offset (distance). (c) Offset bin stack (from geophones and shots placed on the rock glacier).

bedrock is compatible with the velocity of slightly jointed gneiss.

The depths to ice-rich permafrost along profiles A and B were calculated by the Plus-Minus method (Hagedorn, 1959). Depths range between $1 \mathrm{~m}$ and
$10 \mathrm{~m}$, with an average of $4.6 \mathrm{~m}$. For the ice head wave the mean value is $3430 \mathrm{~m} / \mathrm{s}$ for profile $\mathrm{A}(\sigma= \pm 66 \mathrm{~m} / \mathrm{s})$ and $3260 \mathrm{~m} / \mathrm{s}$ for profile B $(\sigma= \pm 70 \mathrm{~m} / \mathrm{s})$. The calculation of the depth to the bedrock takes advantage of the three dimensional (3D) aspect of the shot and 
Table 1 Types of waves used in seismic refraction analysis. Geophone and shots are placed either on the rock glacier (RG) or outside the rock glacier (Out).

\begin{tabular}{|c|c|c|c|c|c|}
\hline Wave type & Shot & Geophone & Offset range $(\mathrm{m})$ & $\mathrm{v}_{\mathrm{p}}(\mathrm{m} / \mathrm{s})$ & Used for the determination of \\
\hline Direct wave & RG & RG & $5-30$ & 950 & Depth to ice-rich permafrost \\
\hline Direct wave & Out & Out & $8-55$ & $1000-2000$ & $\begin{array}{l}\text { Unfrozen till and depth to } \\
\text { the bedrock outside the } \\
\text { rock glacier }\end{array}$ \\
\hline Ice head wave & RG & RG & $35-120$ & & Depth to ice-rich permafrost \\
\hline Profile A & & & & $3363-3527$ & \\
\hline Profile B & & & & $3143-3376$ & \\
\hline Rock head wave & RG & RG & $120-205$ & 4100 & Bedrock surface \\
\hline Rock head wave & Out/RG & RG/Out & $120-265$ & 4100 & Bedrock surface \\
\hline
\end{tabular}

receiver layout and uses a 3D inversion (e.g. Kirchheimer, 1988a, 1988b; Iwasaki, 2002) in which delay times are proxies for refractor depths (Appendix B; Gardner, 1939; Telford et al., 1990). Prior to the inversion, we reduced the travel times of $\mathrm{P}$-waves refracted from the bedrock statically to the top of the ice-rich permafrost by an amount accounting for the debris layer. The delay times were transformed to refractor depths using the velocities $\mathrm{v}_{\text {icePf }}$ and $\mathrm{v}_{\text {bedrock }}$.

The wave types employed for calculation of velocities and depths are summarised in Table 1. In this three-layer model, the bedrock depth calculated by seismic refraction data exceeds the depth of the GPR reflector R1 by $17 \mathrm{~m}$ on average. Because of this significant disagreement, we introduced a seismic low velocity zone (i.e. an unfrozen layer) as a fourth layer between the ice-rich permafrost and the bedrock surface. Figure 8 presents two possible four-layer models, which are in agreement with both the GPR and the seismic refraction data. In the first model, the fourth layer is arranged below the GPR reflector R1 and might represent unfrozen sediments. In the second model, the fourth layer is arranged above the GPR reflector R1 and might represent unfrozen debris. We favour the first model because seismic data acquired in front of the rock glacier indicate the presence of an unfrozen layer with an average thickness of $5 \mathrm{~m}$. This layer is composed of till and its upper surface could well represent the prominent reflector $\mathrm{R} 1$. The velocity of the till $\left(v_{\text {till }} \sim 1600 \mathrm{~m} / \mathrm{s}\right)$ was deduced from seismic data where the layer is outcropping. We derived thicknesses between 3 and $12 \mathrm{~m}$ for the till layer.

\section{Gravimetry}

Gravimetric measurements have been carried out in a number of rock glacier studies (e.g. Klingele and
Vonder Mühll, 1993; Vonder Mühll, 1993; Vonder Mühll and Klingele, 1994) and are summarised in Barsch (1996). Gravimetry yields additional information on density and ice content. In order to constrain the gravity inversion we used the four-layer model of the rock glacier obtained from the GPR and seismic refraction analyses.



Figure 8 The initial seismic three-layer model (M0) and two possible four-layer models (M1, M2) that are consistent with the observed GPR reflector R1. In model M1, the introduced layer is arranged below the GPR reflector (e.g. unfrozen sediments). In contrast, the low velocity zone of model M2 is arranged above R1 (e.g. unfrozen debris) and the bedrock surface corresponds to R1. 
A Scintrex CG-3 gravity meter (accuracy of $\pm 10 \mu \mathrm{Gal})$ was deployed to make 128 measurements on the lower part of the rock glacier (Figure 9a) and at 25 adjoining locations (Figure 5c) in order to estimate the regional trend. The regional density of $2670 \mathrm{~kg} / \mathrm{m}^{3}$, used for the calculation of topographic correction and Bouguer anomaly, corresponds to a regional density map (Granser et al., 1989). A linear regional trend is subtracted from the Bouguer anomaly. The residual values up to $-1 \mathrm{mGal}$ show two minima (Figure 9b). Densities for the debris $\left(d_{\text {debris }}=1920 \mathrm{~kg} / \mathrm{m}^{3}\right)$ and till $\left(d_{\text {till }}=1950 \mathrm{~kg} / \mathrm{m}^{3}\right)$ layers were estimated by a conversion of seismic velocities to density using the relation of Watkins et al. (1972). Finally, modelling of the residual values yielded densities between 1620 and $2120 \mathrm{~kg} / \mathrm{m}^{3}$ for the ice-rich permafrost layer along profiles A and B (Figure 10).

\section{Ice Content}

Based on the gravimetrically derived densities we calculated the relative ice content $i$ using a three-phase model (rock, ice and air) for the ice-rich permafrost within the rock glacier:

$$
d_{\text {icePf }}=i \cdot d_{i c e 0}+(1-i-a) \cdot d_{\text {rockPf }}+a \cdot d_{\text {air }}
$$

In Equation (1) $d_{\text {icePf }}$ is the density of the ice-rich permafrost calculated in the previous section; $d_{\text {iceo }}$ $\left(917 \mathrm{~kg} / \mathrm{m}^{3}\right.$; Andersland and Ladanyi, 2004) and $d_{\text {air }}$ $\left(1.3 \mathrm{~kg} / \mathrm{m}^{3}\right.$ at $\left.0^{\circ} \mathrm{C}\right)$ are the densities of ice and air, respectively. The rock density $d_{\text {rock } P f}\left(2990 \mathrm{~kg} / \mathrm{m}^{3}\right)$ was derived from buoyancy measurements on 11 samples of the debris layer. The relative ice content (Figure 10) calculated from Equation (1) is $\sim 60 \%$ for $a=0$ (two-phase model; rock and ice) and $\sim 45 \%$ for $a=0.1$ (three-phase model; rock, ice and air) along profiles A and B. A one dimensional (1D) model representing the average values (Figure 11) was used to estimate the total ice content $\left(250000 \mathrm{~m}^{3}\right)$ in the lower central part of the rock glacier $\left(0.017 \mathrm{~km}^{2}\right)$ where the surface displacements are uniform.

A sensitivity analysis and evaluation of the accuracy (Appendix C) use this representative 1D model and the


Figure 9 (a) Gravimetric data acquisition and (b) residual Bouguer anomaly. 

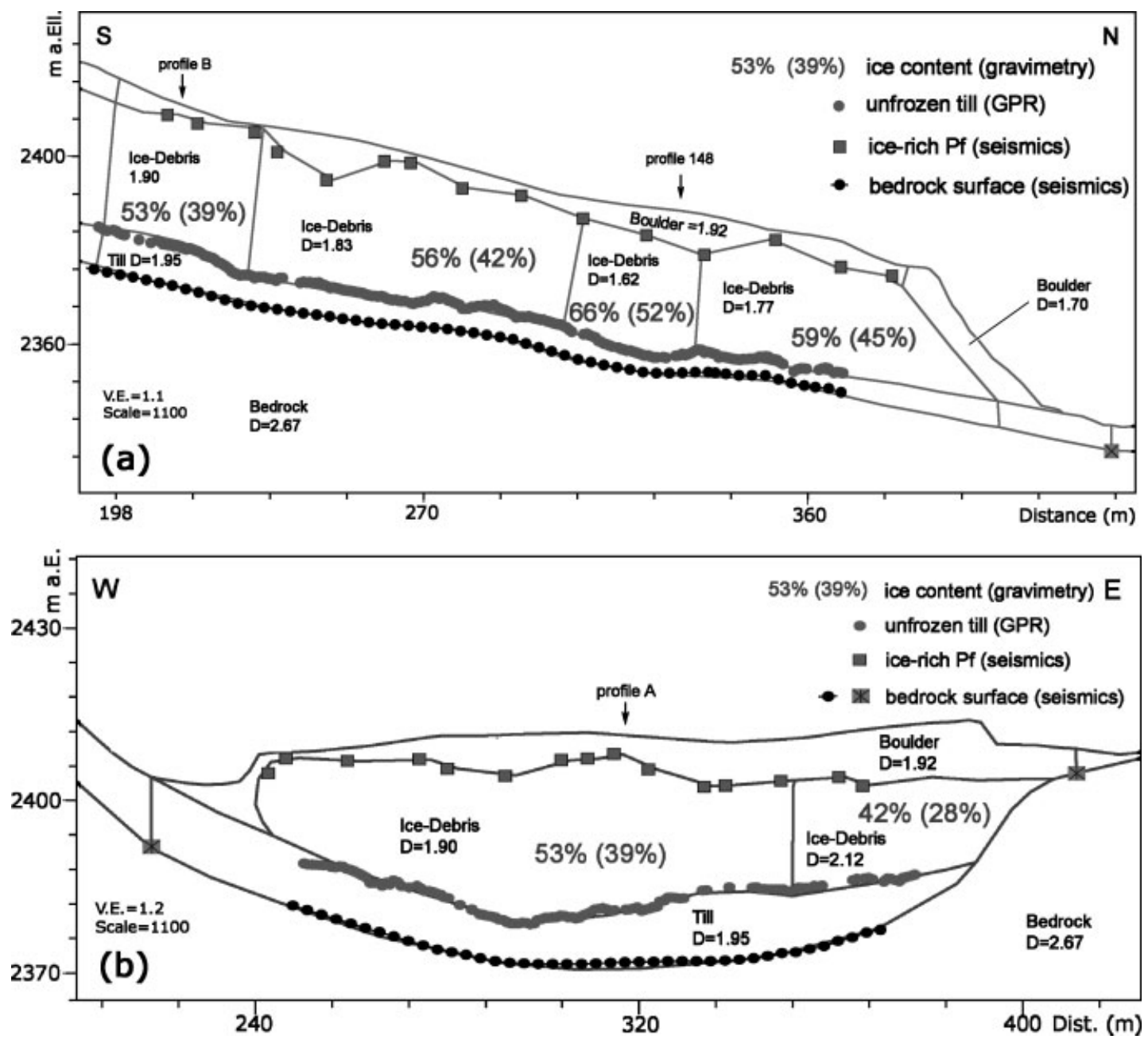

Figure 10 The combined result of GPR, seismic refraction and gravimetry: The density model and ice content on (a) longitudinal profile and (b) transverse profile. Ice content values in parenthesis refer to the three-phase model with $10 \%$ relative air content.

two-phase model of the ice-rich permafrost. Table 2 shows the computed accuracy of all the calculated parameters. The most important parameter, the total ice content of the ice-rich permafrost, has a standard deviation of about $\pm 15 \%$.

\section{Creep Model}

By comparing observed surface velocities and calculated creep velocities, we tested the plausibility of our geophysical interpretation. Creep of mountain permafrost depends mainly on surface slope and ice content, but temperature and air content of the ice are also important parameters. Some studies have used a pure ice body for a tentative description of rock glacier creep (e.g. Kääb et al., 2006) while others determined the parameters for the standard creep expression (e.g. Wagner, 1992). Because of the heterogeneous composition (mixture of debris, silt, water, air and ice) (Hoelzle et al., 1998; Arenson et al., 2002; Musil, 2002) and because the temperature is close to the melting point, the observed parameters for the standard creep expression show large variations (Ikeda et al., 2003; Arenson and Springman, 2005a). Ladanyi (2003) described how the creep of ice/rock mixtures can be calculated using known principles of soil and rock mechanics.

To tentatively describe the creep process we created a rheological model using a refinement of Glen's flow law. Our model uses simplified geometry (representative 1D model, Figure 11) and assumptions (e.g. homogeneous ice/rock concentration). We apply 


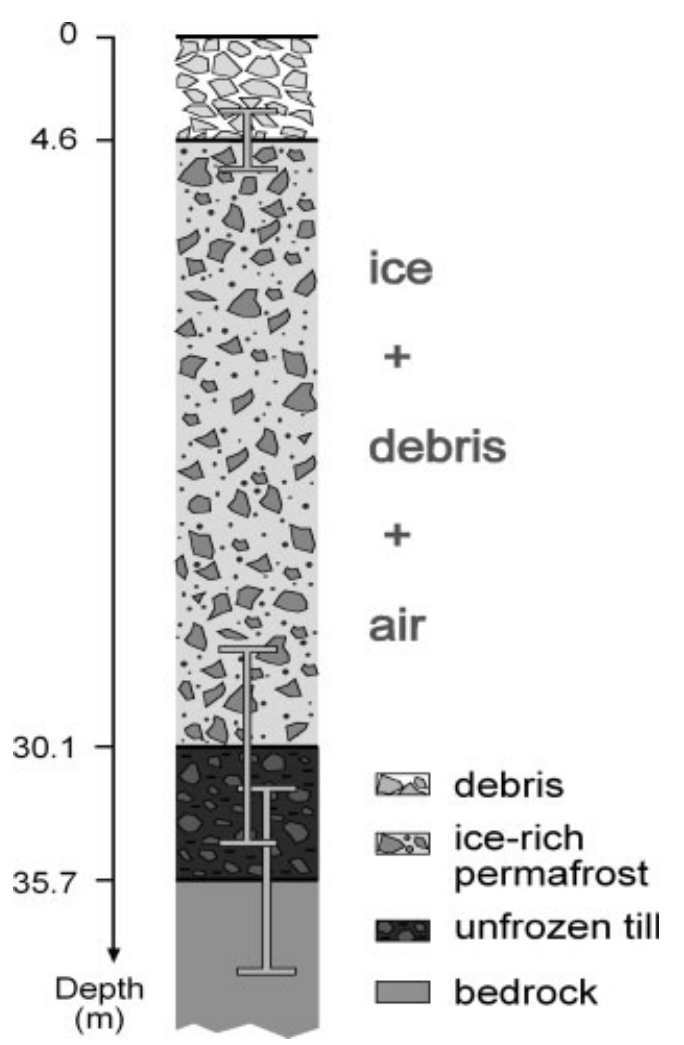

Figure 11 Representative vertical profile with error bars. It is calculated by average values from the profiles (a) and (b) (Figure 10). For calculation of the total ice content as well as the sensitivity and error analysis the lateral extension of the $1 \mathrm{D}$ model is assumed to be 1 in both directions.

Glen's law (Glen, 1955) to describe the rheology of pure ice in the case of simple shear:

$$
\dot{\varepsilon}_{x y}=A \cdot \tau_{x y}^{n}
$$

In Equation (2) $\dot{\varepsilon}_{x y}$ is the shear strain rate, $A$ is a temperature-dependent parameter, $\tau_{x y}$ is the shear stress and $n=3$ is the exponent in the non-linear flow law. An expression of the surface velocity can be derived by integration of Equation (2) (Paterson, 1994; Whalley and Martin, 1992):

$$
\begin{gathered}
v_{x}=(i+a) \cdot 2 \cdot A \cdot \int_{0}^{d h_{\text {icePf }}}\left[\left(\tau_{0}+\frac{g \cdot d_{\text {icePf }} \cdot y \cdot \sin (\alpha)}{1000}\right) \cdot\left(\frac{i+a}{i}\right)\right]^{n} d y \\
\tau_{0}=\frac{g \cdot d_{\text {debris }} \cdot d h_{\text {debris }} \cdot \sin (\alpha)}{1000}
\end{gathered}
$$

In Equation (3) $v_{x}$ is the surface velocity, $g$ is the gravity acceleration and $\alpha$ is the (surface) slope. The quantities $i$ and $a$ describe the relative ice and air content of the rock glacier. Introducing the sum $(i+a)$ in Equation (3) has the effect that flow is only allowed where ice or air exist. The presence of air voids within the ice media causes stress concentrations at the rate of $[(i+a) / i]$. Thickness and density of the ice-rich permafrost are $d h_{\text {icePf }}$ and $d_{\text {icePf }}$. The mean surface slope $\alpha=11.2^{\circ}$ was computed by a leastsquares fit through 128 surface points. The shear stress $\tau_{0}$ (Equation (4)) considers the additional loading by the debris layer. The thickness of the debris layer and its density are $d h_{\text {debris }}$ and $d_{\text {debris. }}$. We used an exponential expression given by Kääb et al. (2006) to calculate the temperature-dependent parameter $A$ (Equation (5)).

$$
A=6.6 \cdot e^{(0 \cdot 4 \cdot T)} \cdot 10^{-15} \mathrm{~s}^{-1}(\mathrm{kPa})^{-3} \quad \text { for } \mathrm{T} \leq 0
$$

We calculated $A$ for ice temperatures of $0,-1,-2$ and $-3{ }^{\circ} \mathrm{C}$ and varied the relative air content between 0

\begin{tabular}{|c|c|c|c|c|c|c|c|c|}
\hline \multirow[t]{3}{*}{ Parameter } & $\mathrm{h}_{\text {till }}$ & $h_{\text {icePf }}$ & $\mathrm{h}_{\text {rock }}$ & $\mathrm{d}_{\text {debris }}$ & $d_{\text {till }}$ & $d_{\text {icePf }}$ & $\mathrm{i}$ & $V_{\text {ice }}$ \\
\hline & \multicolumn{3}{|c|}{ Depth $(m)$ to the: } & \multicolumn{3}{|c|}{ Density $\left(\mathrm{g} / \mathrm{cm}^{3}\right)$ of the: } & \multirow{2}{*}{$\begin{array}{l}\text { Relative ice } \\
\text { content }\end{array}$} & \multirow{2}{*}{$\begin{array}{c}\text { Total ice } \\
\text { content }\left(\mathrm{m}^{3}\right)\end{array}$} \\
\hline & Till layer & $\begin{array}{l}\text { Ice-rich } \\
\text { permafrost }\end{array}$ & Bedrock & $\begin{array}{c}\text { Debris } \\
\text { layer }\end{array}$ & $\begin{array}{c}\text { Till } \\
\text { layer }\end{array}$ & $\begin{array}{l}\text { Ice-rich } \\
\text { permafrost }\end{array}$ & & \\
\hline Abs. value & 30.1 & 4.6 & 35.2 & 1.92 & 1.95 & 1.79 & 0.577 & 14.7 \\
\hline$\sigma$ & 4.2 & 1.4 & 4.2 & 0.033 & 0.087 & 0.115 & 0.057 & 1.8 \\
\hline$\sigma(\%)$ & 14 & 30 & 12 & 2 & 4 & 6 & 10 & 14 \\
\hline
\end{tabular}
and $20 \%$ to derive creep velocities using Equation (3) (Figure 12). The magnitudes of the calculated creep

Table 2 Accuracy of the determined parameters as result of an analytical covariance error propagation using the two-phase model and the representative 1D model ( $\sigma=$ standard deviation). 


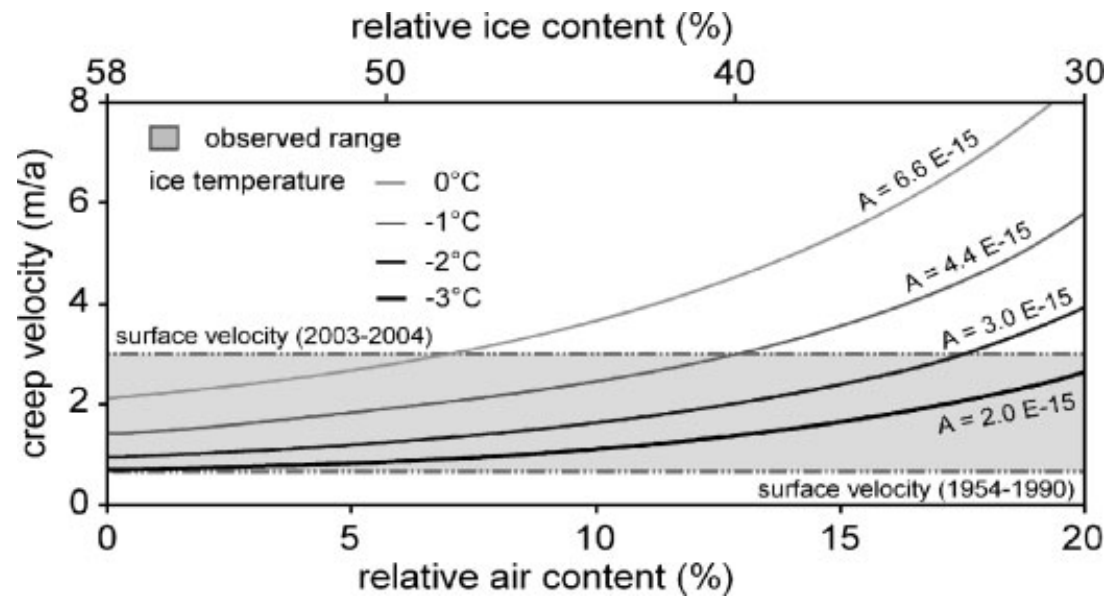

Figure 12 Effect of increasing relative air content on the creep velocity when the ice temperature varies between 0 and $-3^{\circ} \mathrm{C}$. The grey area displays the range of observed surface velocities for the lower part of the rock glacier.

velocities agree with the observed surface velocities, which point towards the validity of the geophysical model. Our model was also tested with various values for the parameters $A, n, i$ and $a$ (Wagner, 1992; Paterson, 1994; Ikeda et al., 2003; Arenson and Springman, 2005a). In particular, a 55\% ice content (Arenson and Springman, 2005a) gives a creep velocity of $2.96 \mathrm{~m} / \mathrm{a}$, very similar to that observed in the field.

The geophysical model was also tested to see if it can qualitatively explain the increase in surface velocities observed during the last decade. A surface velocity of $\sim 0.6 \mathrm{~m} / \mathrm{a}$ between 1954 and 1990 can be explained by an ice temperature of $\sim-3^{\circ} \mathrm{C}$ and almost zero air content. Surface velocities of $\sim 3 \mathrm{~m} / \mathrm{a}$ between 2003-04 can be produced by increasing internal deformation caused by a combination of higher ice temperature $\left(0>\mathrm{T}^{\circ} \mathrm{C}>-1\right)$ and air content $(5<a<15 \%)$. However, because of the lack of information on the relative air content, ice temperature and their recent variations, the possible onset of sliding processes to explain the increase in surface velocity cannot be excluded. Internal sliding can occur between ice and debris, or in a distinct shear zone ('soft layer') within the permafrost body (Arenson et al., 2002; Kääb et al., 2006). At the Reichenkar rock glacier, basal sliding could take place along the water-saturated, fine-grained till layer which lies between the ice-rich permafrost and the bedrock.

It should be noted that a homogenous ice/debris concentration in vertical direction was used in the creep model. There are other possible ice/debris concentrations. For example, if most of the ice is concentrated in the upper part of the permafrost layer, the creep model (at temperatures of $0^{\circ} \mathrm{C}$ ) produces creep velocities that are too low.

\section{CONCLUSIONS}

A combination of GPR, seismic refraction and gravimetry was successful in revealing the internal structure and the ice content of the Reichenkar rock glacier, and resulted in a four-layer model. The debris layer has an average thickness of $4.6 \mathrm{~m}$ and is underlain by ice-rich permafrost. At the base of the ice-rich permafrost, a prominent reflector was detected by GPR and interpreted as an unfrozen till layer. This reflector is located a few metres above the surface of the bedrock, which was clearly detected by seismic refraction. The average thickness of the ice-rich permafrost is about $25 \mathrm{~m}$. The geophysical data indicate that the ice-rich permafrost is composed of about $60 \%$ ice in the case of a two-phase model (rock and ice) or by about $45 \%$ ice, if a relative air content of $10 \%$ is assumed (three-phase model).

The strengths of the geophysical investigations are:

- The combination of GPR and seismic refraction data allows the complex structure of the rock glacier (e.g. seismic low velocity zone on top of the bedrock) to be resolved.

- The cost-effective 3D refraction seismic layout can be applied to determine the bedrock surface.

- The density of the ice-rich permafrost is determined as a unique parameter (there is only one free parameter in the gravimetric model). 
- The rheological model can be used as benchmark for the geophysical model.

A sensitivity analysis of the total ice content shows its dependency on the following parameters: $d_{\text {rockPf }}, \operatorname{del}_{\text {icePf }}, v_{\text {till,gpr }}, t_{g p r}$ (Appendix C). The estimated parameter $v_{\text {till }}$ does not greatly affect the computed ice content.

Based on the structural model and the ice content we calculated the creep velocity of the rock glacier by an extension of Glen's flow law to a homogenous three-phase model (rock, ice and air) for the ice-rich permafrost. An additional shear stress caused by the load of the debris layer was also taken into account. Calculated creep velocities were in agreement with observed values within the range of uncertainty of parameters of the flow law. Plausible explanations for the recent acceleration of surface velocities are compatible with the geophysical model.

\section{ACKNOWLEDGEMENTS}

The investigations were funded by the 'Fonds zur Förderung der wissenschaftlichen Forschung' FWF (Austrian Science Foundation), project P 15218. The authors wish to express their special thanks to K.H. Roch, M. Behm and W. Chwatal who critically commented on the manuscript. Further, we gratefully acknowledge A. Rohatsch for determination of the density of our field samples. In addition, we acknowledge the comments of two anonymous reviewers that helped to improve the manuscript.

\section{REFERENCES}

Andersland OB, Ladanyi B. 2004. Frozen Ground Engineering, Second edition, 363pp. John Wiley \& Sons, Inc.: Hoboken, New Jersey.

Arcone SA, Lawson DE, Delaney AJ. 1995. Short-pulse radar wavelet recovery and resolution of dielectric contrasts within englacial and basal ice of Matanuska Glacier, Alaska, USA. Journal of Glaciology 41(137): 68-86.

Arcone SA, Lawson DE, Delaney AJ, Strasserz JC, Strasser JD. 1998. Ground-penetrating radar reflection profiling of groundwater and bedrock in an area of discontinuous permafrost. Geophysics 63(5): 15731584.

Arenson L. 2002. Unstable Alpine permafrost: A potentially important natural hazard - variations of geotechnical behaviour with time and temperature. $\mathrm{PhD}$ thesis, Swiss Federal Institute of Technology, Zurich, Switzerland. Diss. ETH No. 14801. Available: http://e-collection.ethbib.ethz.ch/show?type=diss\& nr $=14801$ [14 November 2006].
Arenson L, Springman S. 2005a. Mathematical descriptions for the behaviour of ice-rich frozen soils at temperatures close to $0^{\circ} \mathrm{C}$. Canadian Geotechnical Journal 42: 431-442.

Arenson L, Springman S. 2005b. Triaxial constant stress and constant strain rate tests on ice-rich permafrost samples. Canadian Geotechnical Journal 42: 412 430.

Arenson L, Hoelzle M, Springman S. 2002. Borehole Deformation Measurements and Internal Structure of Some Rock Glaciers in Switzerland. Permafrost and Periglacial Processes 13: 117-135. DOI: 10.1002/ ppp.414

Arenson L, Johansen MM, Springman S. 2004. Effects of Volumetric Ice Content and Strain Rate on Shear Strength under Triaxial Conditions for Frozen Soil Samples. Permafrost and Periglacial Processes 15: 261-271. DOI: 10.1002/ppp.498

Barsch D. 1971. Rock glaciers and ice-cored moraines. Geografiska Annaler 53: 203-206.

Barsch D. 1973. Refraktionsseismische Bestimmung der Obergrenze des gefrorenen Schuttkörpers in verschiedenen Blockgletschern Graubündens, Schweizer Alpen. Zeitschrift für Gletscherkunde und Glazialgeologie 9(1-2): 143-167.

Barsch D. 1996. Rockglaciers. Indicators for the Present and Former Geoecology in High Mountain Environments. Springer-Verlag: Berlin.

Berthling I, Etzelmüller B, Isaksen K, Sollid JL. 2000. Rock Glaciers on Prins Karls Forland. II: GPR Soundings and the Development of Internal Structures. Permafrost and Periglacial Processes 11: 357-369.

Berthling I, Etzelmüller B, Wale M, Sollid JL. 2003. Use of Ground Penetrating Radar (GPR) soundings for investigating internal structures in rock glaciers. Examples from Prins Karls Forland, Svalbard. Zeitschrift für Geomorphologie Suppl. 132: 103 121.

Chesi G, Geissler S, Krainer K, Mostler W, Weinhold T. 2003. 5 Jahre Bewegungsmessungen am aktiven Blockgletscher Inneres Reichenkar (westlichen Stubaier Alpen) mit der GPS-Methode. XII. Int. Geodätische Woche Obergurgl 201-205.

Degenhardt JJ. 2002. A model for the development of a lobate alpine rock glacier in southwest Colorado, USA: Implications for water on Mars. $\mathrm{PhD}$ thesis, Texas A\&M University. Available: http://repositories. tdl.org/handle/1969.1/320 [6 October 2007].

Degenhardt JJ, Giardino JR. 2003. Subsurface investigation of a rock glacier using ground-penetrating radar: Implications for locating stored water on Mars. Journal of Geophysical Research 108 E4: 8036, doi: 10.1029/2002JE001888.

Degenhardt JJ, Giardino JR, Junck MB. 2003. GPR survey of a lobate rock glacier in Yankee Boy Basin, Colorado, USA. In Ground Penetrating Radar in Sediments, Bristow CS, Jol HM (eds). Geological Society: London; Spec. Publ. 211: 167-179. 
Gardner LW. 1939. An areal plan for mapping subsurface structure by refraction shooting. Geophysics 4: 247-259.

Glen JW. 1955. The creep of polycrystaline ice. Proc. $R$. Soc. London Ser. A 228: 519-538.

Granser H, Meurers B, Steinhauser P. 1989. Apparent density mapping and $3 \mathrm{~d}$ gravity inversion in the eastern alps.pdf. Geophysical Prospecting 37: 279-292.

Haeberli W. 1985. Creep of Mountain Permafrost: Internal Structure and Flow of Alpine Rock Glaciers. Mitteilungen der Versuchsanstalt für Wasserbau, Hydrologie und Glaziologie ETH Zürich 77: 1-142.

Haeberli W. 1990. Pilot Analyses of Permfrost Cores from the Active Rock Glacier Murtèl, Piz, Corvatsch, Eastern Swiss Alps. Mitteilungen der Versuchsanstalt für Wasserbau, Hydrologie und Glaziologie Arbeitsheft 9.

Haeberli W, Wächter HP, Schmid W, Sidler C. 1982. Erste Erfahrungen mit dem US Geological Survey Monopuls Radioecholot im Firn. Eis und Permafrost der Schweizer Alpen. Mitteilungen der Versuchsanstalt für Wasserbau, Hydrologie und Glaziologie ETH Zürich Arbeitsh 6: 1-23.

Haeberli W, Hallet B, Arenson L, Elconin R, Humlum O, Kääb A, Kaufmann V, Ladanyi B, Matsuoka N, Springman S, Vonder Mühll D. 2006. Permafrost creep and rock glacier dynamics. Permafrost and Periglacial Processes 17: 189-214. DOI: 10.1002/ppp.561

Hagedorn JG. 1959. The plus-minus method of interpreting seismic refraction sections. Geophysical Prospecting 7: 179-181.

Hauck C. 2001. Geophysical methods for detecting permafrost in high mountains. PhD thesis. Swiss Federal Institute of Technology, Zurich, Switzerland. Diss. ETH No. 14163. Mitt. Versuchsanst. Wasserbau, Hydrologie u. Glaziologie der ETH Zürich 171, 204pp. Available: http://e-collection.ethbib.ethz.ch/ show?type $=$ diss $\& n r=14163$ [14 November 2006].

Hauck C, Vonder Mühll D. 2003a. Evaluation of geophysical techniques for application in mountain permafrost studies. Zeitschrift für Geomorphologie Suppl.-Bd. 132: 159-188.

Hauck C, Vonder Mühll D. 2003b. Permafrost monitoring using DC resistivity tomography. Proceedings of the 8th International Conference on Permafrost 21-25 July 2003, Zurich, Switzerland. Balkema, The Netherlands.

Hauck C, Vonder Mühll D, Maurer H. 2003. DC resistivity tomography to detect and characterize mountain permafrost. Geophysical Prospecting 51: 273-284

Hauck C, Isaksen K, Vonder Mühll D, Sollid JL. 2004. Geophysical surveys designed to delineate the altitudinal limit of mountain permafrost: an example from Jotunheimen, Norway. Permafrost and Periglacial Processes 15: 191-205. DOI: 10.1002/ppp.493

Hoelzle M, Wagner S, Kääb A, Vonder Mühll D. 1998. Surface movement and internal deformation of ice-rock mixtures within rock glaciers at Pontresina-Schafberg, Upper Engadin, Switzerland. Proceedings of the 7th International Conference on Permafrost
Yellowknife, Canada, 23-27 June 1998. Collection Nordicana, Canada; 465-472.

Ikeda A, Matsuoka N, Kääb A. 2003. A rapidly moving small rock glacier at the lower limit of the mountain permafrost belt in the Swiss Alps. Proceedings of the 8th International Conference on Permafrost, Zurich. Balkema, The Netherlands. 1: 455-460.

Isaksen K, Ødegard RS, Eiken T, Sollid JL. 2000. Composition, flow and development of two tongue-shaped rock glaciers in the permafrost of Svalbard. Permafrost and Periglacial Processes 11: 241-257.

Iwasaki T. 2002. Extended time-term method for identifying lateral structural variations from seismic refraction data. Earth Planets Space 54: 663-677.

Kääb A, Frauenfelder R, Roer I. 2006. On the response of rockglacier creep to surface temperature increase. Global and Planetary Change 56(1-2): 172-187. DOI: $10.1016 /$ j.gloplacha.2006.07.005.

King L. 1976. Permafrostuntersuchungen in Tarfala (Schwedisch-Lappland) mit Hilfe der Hammerschlagseismik. Zeitschrift für Gletscherkunde und Glazialgeologie 12(2): 187-204.

King L, Fisch W, Haeberli W, Waechter HP. 1987. Comparison of resistivity and radio-echo soundings on rockglacier permafrost. Zeitschrift für Gletscherkunde und Glazialgeologie 23(1): 77-97.

Kirchheimer F. 1988a. 3-D refraction statics by weighted least-squares inversion. SEG Expanded Abstracts 7: 794.

Kirchheimer F. 1988b. A tomographic approach to 3-D refraction statics. 5th Annual Meeting of the European Association of Exploration Geophysicists, Proceedings, The Hague, Netherlands.

Klingele E, Vonder Mühll D. 1993. Gravimetrische Untersuchungen im Permafrost des Blockgletschers Murtèl-Corvatsch (Oberengadin). Vermessung, Photogrammetrie, Kulturtechnik 91(10): 575-580.

Krainer K, Mostler W. 2000a. Aktive Blockgletscher als Transportsysteme für Schuttmassen im Hochgebirge: Der Reichenkar Blockgletscher in den westlichen Stubaier Alpen. Geoforum Umhausen 1: 28-43.

Krainer K, Mostler W. 2000b. Reichenkar rock glacier: a glacier derived debris-ice system in the Western Stubai Alps, Austria. Permafrost and Periglacial Processes 11: 267-275.

Krainer K, Mostler W. 2002. Hydrology of active rock glaciers; Examples from the Austrian Alps. Arctic, Antarctic, and Alpine Research 34(2): 142-149.

Krainer K, Mostler W. 2006. Flow velocities of active rock glaciers in the Austrian Alps. Geografiska Annaler 88(4): 267-280. DOI:10.1111/j.0435-3676. 2006.00300.x.

Krainer K, Mostler W, Span N. 2002. A glacier-derived, ice-cored rock glacier in the western Stubai Alps (Austria): Evidence from ice exposures and ground penetrating radar investigation. Zeitschrift für Gletscherkunde und Glazialgeologie 38(1): 2134.

Ladanyi B. 2003. Rheology of ice/rock systems and interfaces. Proceedings of the 8th International Con- 
ference on Permafrost 21-25 July 2003, Zurich, Switzerland. Balkema, The Netherlands; 621-625.

Lehmann F, Green AG. 2000. Topographic migration of georadar data: Implications for acquisition and processing. Geophysics 65(3): 836-848.

Maurer H, Hauck C. 2007. Geophysical imaging of alpine rock glaciers. Journal of Glaciology 53(180): 110-120.

Mikhail EM. 1976. Observations and least squares. IEPA Dun-Donnelley: New York.

Musil M. 2002. Inverting seismic and georadar data with applications to the Muragl rock glacier. $\mathrm{PhD}$ thesis. Diss. ETH No. 14581. Institute for Geophysics, Swiss Federal Institute of Technology, Zurich. Available: http://e-collection.ethbib.ethz.ch/show?type $=$ diss \&nr= 14581 [14 November 2006].

Musil M, Maurer H, Green AG, Horstmeyer H, Nitsche FO, Vonder Mühll D, Springman S. 2002. Shallow seismic surveying of an Alpine rock glacier. Geophysics 67(6): 1701-1710.

Musil M, Maurer H, Hollinger K, Green AG. 2006. Internal structure of an alpine rock glacier based on crosshole georadar traveltimes and amplitudes. Geophysical Prospecting 54: 273-285.

Paterson WSB. 1994. The Physics of Glacier, 3rd Edition. Butterworth Heinemann, Elsevier Science: Oxford, UK.

Potter N. 1972. Ice-Cored Rock Glacier, Galena Creek, Northern Absaroka Mountains, Wyoming. Geological Society of America Bulletin 83: 3025-3058.

Raymond CF. 1980. Valley glaciers. In Dynamics of Snow and Ice Masses, Colbeck SC (ed.). Academic Press: New York; 79-139.

Reissmann G. 1976. Die Ausgleichungsrechnung, Grundlagen und Anwendung in der Geodäsie. 5. Auflage. VEB Verlag für Bauwesen: Berlin.

Schmöller R, Fruhwirth R. 1996. Komplexgeophysikalische Untersuchungen auf dem Dösener Blockgletscher (Hohe Tauern, Österreich). Beiträge zur Permafrostforschung in Österreich, Graz, Band 33.

Stuart GW, Gamble N, Murray T, Hayes K, Hobson A. 2003. Characterization of englacial channels by ground-penetrating radar: An example from austre Brøggerbreen, Svalbard. Journal of Geophysical Research 108(B11): 2525. DOI:10.1029/2003JB002435.

Telford WM, Geldard LP, Sheriff RE. 1990. Applied Geophysics. Cambridge University Press: New York.

Vonder Mühll D. 1993. Geophysikalische Untersuchungen im Permafrost des Oberengadins. Diss. ETH No. 10107, 110pp. Mitteilungen der Versuchsanstalt für Wasserbau, Hydrologie und Glaziologie: Zurich, Switzerland.

Vonder Mühll D, Holub P. 1992. Borehole logging in Alpine permafrost, Upper Engadin, Swiss Alps. Permafrost and Periglacial Processes 3(2): 125-132.

Vonder Mühll D, Klingele E. 1994. Gravimetrical investigation of ice rich permafrost within the rock glacier Murtèl-Corvatsch. Permafrost and Periglacial Processes 5(1): 13-24.

Vonder Mühll D, Hauck C, Lehmann F. 2000. Verification of geophysical models in Alpine permafrost using borehole information. Annals of Glaciology 31: 300-306.

Vonder Mühll D, Hauck C, Gubler H, McDonald R, Russill N. 2001. New GeophysicalMethods of Investigating the Nature and Distribution of Mountain Permafrost with Special Reference to Radiometry Techniques. Permafrost and Periglacial Processes 12: 27-38. DOI: $10.1002 /$ ppp.382.

VonderMühll D, Hauck C, Gubler H. 2002. Mapping of mountain permafrost using geophysical methods. Progress in Physical Geography 26(4): 643-660.

Vonder Mühll D, Arenson L, Springman S. 2003. Temperature conditions in two Alpine rock glaciers. Proceedings of the 8th International Conference on Permafrost 21-25 July 2003, Zurich, Switzerland. Balkema, The Netherlands; 1195-1200.

Wagner S. 1990. Ice fabrics and air bubbles. In Pilot Analyses of Permfrost Cores from the Active Rock Glacier Murtèl, Piz Corvatsch, Eastern Swiss Alps. Mitteilungen der Versuchsanstalt für Wasserbau, Hydrologie und Glaziologie Arbeitsheft VAW/ ETHZ 9: 16-22.

Wagner S. 1992. Creep of Alpine Permafrost, Investigation on the Murtel Rock Glacier. Permafrost and Periglacial Processes 3: 157-162.

Wale M. 1999. Indre strukturer i utvalgte steinbreer pa Svalbard. MSc thesis, Department of Physical Geography, University of Oslo.

Watkins JS, Walters LA, Godson RH. 1972. Dependency of in-situ compressional-wave velocity on porosity in unsaturated rocks. Geophysics 37(1): 29-35.

Whalley WB, Martin HE. 1992. Rock glaciers: II models and mechanisms. Progress in Physical Geography 16(2): 127-186.

\section{APPENDIX A: LIST OF SYMBOLS}

$\mathrm{d}_{\text {air0 }}$

$\mathrm{d}_{\text {debris }}$

$\mathrm{d}_{\text {ice } 0}$

$\mathrm{d}_{\text {icePf }}$

$\mathrm{d}_{\text {till }}$

$\mathrm{d}_{\text {rockPf }}$

del $_{\text {bedrock }}$

$\operatorname{del}_{\text {icePf }}$

$\mathrm{dh}_{\text {debris }}$

$\mathrm{dh}_{\text {icePf }}$

$\mathrm{h}_{\mathrm{icePf}}$ relative air content of the ice-rich permafrost

density of air

density of the debris layer

density of ice fractionally below zero celsius

density of the ice-rich permafrost (density model)

density of the till layer

density of rock samples from the debris layer

computed delay time of the bedrock surface

computed delay time of the ice-rich permafrost

thickness of the debris layer

thickness of the ice-rich permafrost

depth to the ice-rich permafrost 


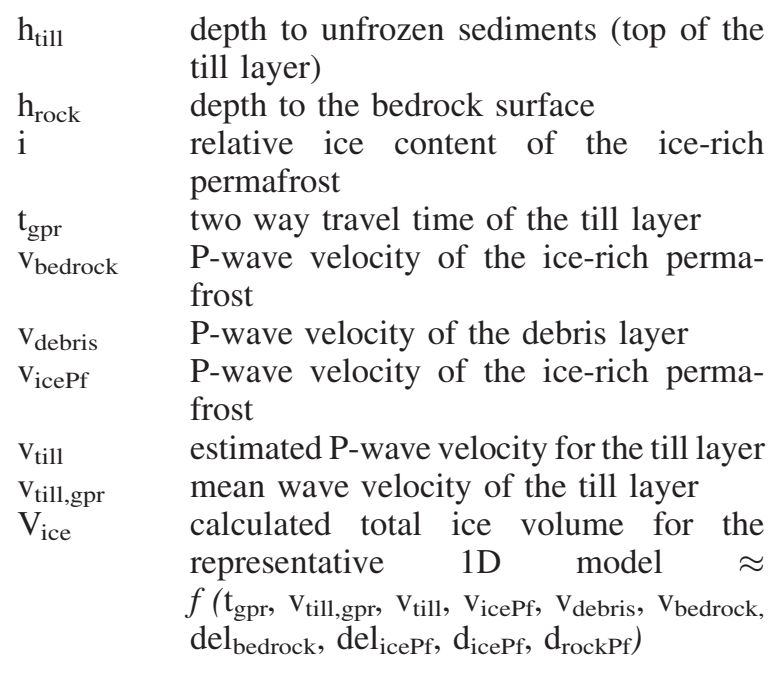

\section{APPENDIX B: THE PRINCIPLE OF DELAY TIME MODELLING}

A travel time $t$ of a wave passing a refractor can be decomposed according to:

$$
t(a \circ f)=t d_{S R C}+\frac{a o f f}{v_{p}}+t d_{R C V}
$$

with

$t \quad$ travel time of a refracted wave

$t d_{S R C}, t d_{R C V}$ refractor (here: bedrock) delay times

at source and receiver locations

aoff absolute offset (distance between source and receiver)

$v_{P} \quad$ refractor velocity at the CMP-location

$2 \mathrm{D}$ and $3 \mathrm{D}$ refraction surveys lead to equation systems based on (B1) which can be solved for laterally variable delay times and refractor velocities. In case of a $1 \mathrm{D}$ velocity distribution $v_{P}(\mathrm{z})$ above and a constant velocity $v_{P}$ below the refractor (bedrock), the delay time $t d$ and the depth $D$ of the refractor at an arbitrary location are related by:

$$
t d=\int_{z=0}^{z=D} \sqrt{\frac{1}{v_{P}(z)^{2}}-\frac{1}{v_{P}^{2}}} \cdot d z
$$

In case of a dipping refractor or lateral variations of $v_{P}$ the delay time depends on the azimuth of the ray.

\section{APPENDIX C: SENSITIVITY ANALYSIS AND ACCURACY}

In order to define how accurate an observation must be, the analytical covariance error propagation was applied. The standard deviation of the total ice content of the ice-rich permafrost as well as the sensitivity of all unknown parameters is important. Therefore, we have to declare a functional relation between observations (observables: velocities, delay times, densities) and unknown parameters (depths to each layer, densities, relative and total ice content). We used a two-phase model (rock and ice) and a representative 1D model of the rock glacier (Figure 11). The covariance propagation was developed by C.F. Gauß and is mainly used in geodesy. It is only valid for random and not systematic errors (e.g. model errors). The covariance propagation law (e.g. Mikhail, 1976; Reissmann, 1976) is:

$$
\sum_{y y}=A \cdot \sum_{x x} \cdot A^{T}
$$

It uses the functional matrix $A$ (Jacobi matrix) and the covariance matrix $\Sigma_{x x}$. The elements of matrix $A$ contain the first derivative of each observation with respect to each equation and the matrix $\Sigma_{x x}$ contains all variances $\left(\sigma^{2}\right)$ for the observations. As a result, all standard deviations from the unknown parameters are obtained $\left(\Sigma_{y y}\right)$. For the total ice content, a standard deviation of $\pm 15 \%$ can be quoted (Table 2 ).

To test the sensitivity of the geophysical model we applied (for each test run and observation) the value of the half-standard deviation to the corresponding absolute value. Relative values of 5\% and $10 \%$ were also applied to each observation or their corresponding standard deviation. Analysis showed that the seismic velocity of the till layer $\left(v_{\text {till }}\right)$ has a relatively small effect on the final ice volume. However, the parameters $d_{\text {rockPf }}$ delicePf, $v_{\text {till,gpr }}$, and $t_{g p r}$ have significant effects.

Figure 11 shows the simplified internal structure as result of the determined quantities and associated error bars (Table 2). For covariance error propagation, the following standard deviations were used: for $t_{\text {gpr }}, v_{\text {till,gpr }}, v_{\text {till }} \pm 10 \%$ of their total value. The standard deviations from the parameters del $_{\text {bedrock }}$, $\operatorname{del}_{\text {icePf }}, d_{\text {icePf }}$ and $d_{\text {rockPf }}$ could be calculated as $1.56 \mathrm{~ms}, 1.3 \mathrm{~ms}, 0.03 \mathrm{mGal}$ and $0.07 \mathrm{~g} / \mathrm{cm}^{3}$ respectively. For the parameters $v_{\text {icePf }}, v_{\text {debris }}$, and $v_{\text {bedrock }}$ a standard deviation of $\pm 70 \mathrm{~m} / \mathrm{s}$ was used. The computation of the bedrock surface relies heavily on the GPR data. 